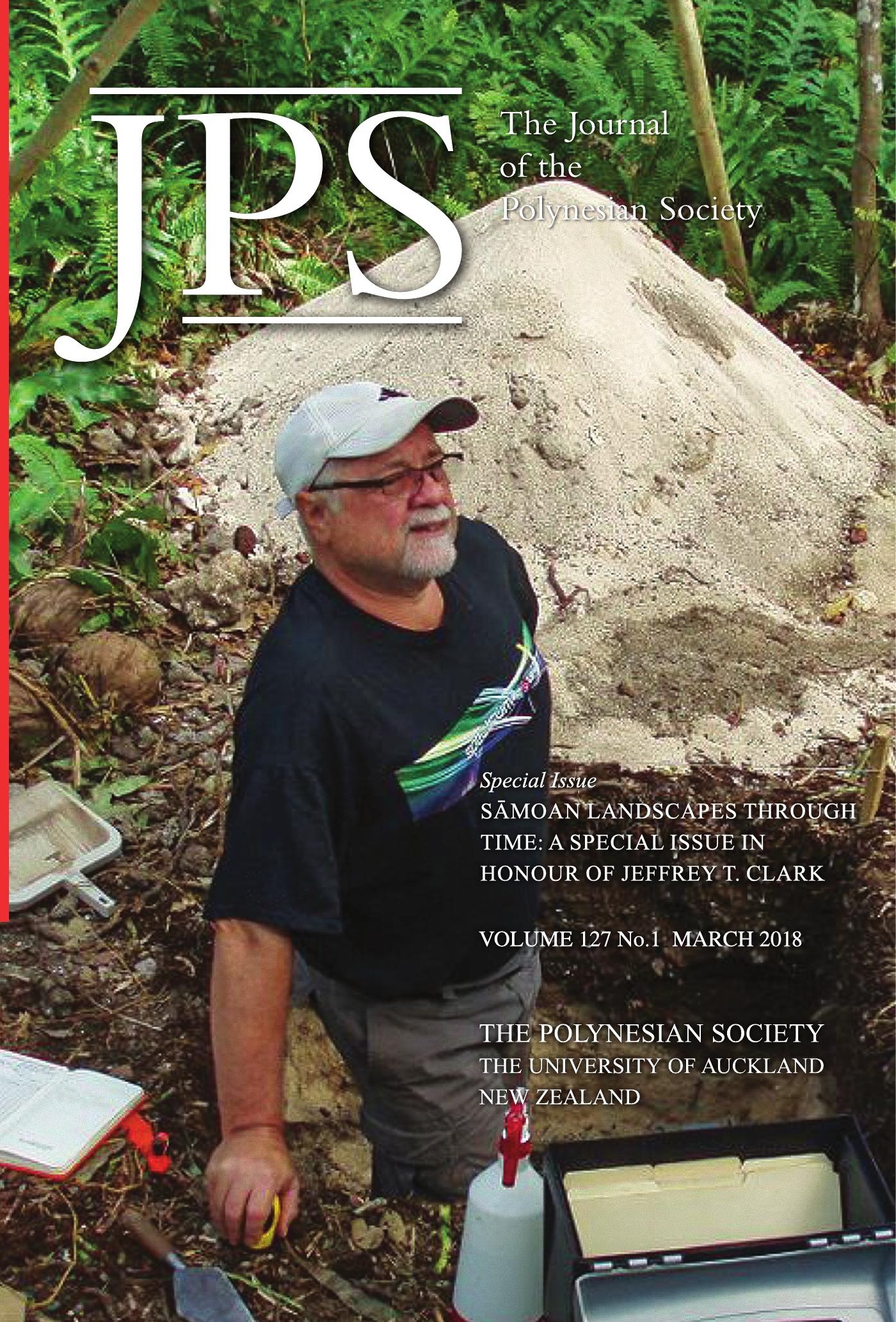




\title{
SĀMOA'S HIDDEN PAST: LiDAR CONFIRMS INLAND SETTLEMENT AND SUGGESTS LARGER POPULATIONS IN PRE-CONTACT SĀMOA
}

\author{
GREGORY JACKMOND \\ National University of Samoa \\ DIONNE FONOTI \\ National University of Samoa \\ MATIU MATAVAI TAUTUNU \\ National University of Samoa
}

In this communication we report the findings of extensive inland settlement in Palauli District, Savai'i, made possible with the use of LiDAR-guided ${ }^{1}$ fieldwork. The surveys were conducted in April and June 2017 by the authors with students and other staff of the Centre for Samoan Studies, National University of Samoa. The findings have relevance to earlier scholarly debates on the location of settlements and the population of Sāmoa before European contacts in the 18th and 19th centuries, for which there was no consensus. Some, such as Watters (1958) and Pirie (1964), asserted that the nucleated coastal settlement patterns in Sāmoa observed and described in the 19th century were likely to be representative of those in the ancient past, a perception held by most Sāmoans today. In this view, villages have always been concentrated along the coast, often nucleated around malae 'central meeting spaces' (Pratt 1893: 201) with one or more large meeting houses (falefono, fale talimālō) of the highest-ranking chiefs located beside or within them. It was assumed that a very few villages extended inland, and those were thought to have been refuges in times of strife and not permanent settlements (e.g., Wright 1963). These assumptions were contradicted by Golson (1969) and Davidson (1969) who refer to the archaeological evidence that existed then to assert that inland settlement was extensive in some areas. Settlement pattern studies of Letolo, Sāpapali'i and Mt Olo (Jennings and Holmer 1980; Jennings et al.1976, 1982) have also shown settlements ranging from the coast to several kilometres inland throughout Palauli and Sāmoa, and other earlier studies by Buist (1969) and Davidson (1969) have hinted at the same. Recent studies of settlement patterns and land use on the small islands of Manono in independent Samoa (Sand et al. 2012, 2013) and the Manu'a group, American Samoa (Quintus 2015; Quintus et al. 2015, 2017) reveal extensive land use, as would be expected given their limited areas. 
However, there have been few surveys of inland areas on the large islands of 'Upolu or Savai' $i$, and none since the late 1970s (Jennings and Holmer 1980; Jennings et al.1976, 1982). Some of this evidence suggests that the population may have been greater than estimates made in the 19th century, although McArthur (1967: 104, 115) disagreed. More recently, a detailed consideration has been made by Green (2007) of the archaeological evidence of settlement and Sāmoa's population prior to European contact. He suggested that further research would likely reveal a much larger population in previous centuries than the population of around 50,000 recorded for the archipelago by missionaries in the mid-19th century. The LiDAR-guided field research reported here adds weight to Green's proposition, as well as to the body of evidence that settlement patterns and land use in the past differed from observations recorded in the 19th century.

\section{ARCHAEOLOGICAL FIELD SURVEY FINDINGS IN PALAULI (2017)}

In April and June 2017 a research team from the National University of Samoa's Centre for Samoan Studies commenced an archaeological survey in the inland areas of the villages of Vaito 'omuli and Fa'aala, Palauli District, on the island of Savai' $i$. The last time an archaeological survey was conducted in Palauli was in the late 1970s by archaeologist Gregory Jackmond, who had mapped an extensive ancient settlement (Fig. 1) of over 200 hectares, inland of Vailoa Village, on the Letolo plantation in Palauli District, Savai' $i$ (see Green 2007: 220-21; Scott 1969). The mapped settlement area surrounds the great Pulemelei stone mound there (see Martinsson-Wallin 2016). Earlier work in the Palauli area was included in a rudimentary survey of Savai' $i$, which located several sites in the Palauli area ranging from isolated mounds to scattered settlements (Scott 1969).

\section{Background to the Research Project}

The 2017 survey is part of a two-year project funded by the U.S. Department of State's Ambassadors Fund for Cultural Preservation that was led by the authors. Palauli East and Sātupa' itea East are located on the island of Savai' $i$ and are parts of two of the 11 traditional districts $(i t \bar{u} m \bar{a} l \bar{l})$ of Samoa. They were chosen to further investigate Jackmond's findings from the 1970s and to follow up on work done by Helene Martinsson-Wallin, Paul Wallin and others in 2002-2004 on the Pulemelei Mound (see Martinsson-Wallin 2016). The first objective of the survey was to improve the estimates of the historical size and population of Palauli East. The second objective was to collect information on the size and location of ancient Sāmoan settlements made up of archaeological features such as house platforms (tülagafale), pavements (paepae), star mounds (fetuma 'a), earthen ovens (umu ele 'ele), walls $(p \bar{a})$ and walkways (aualasavali) to compare with previous surveys in 


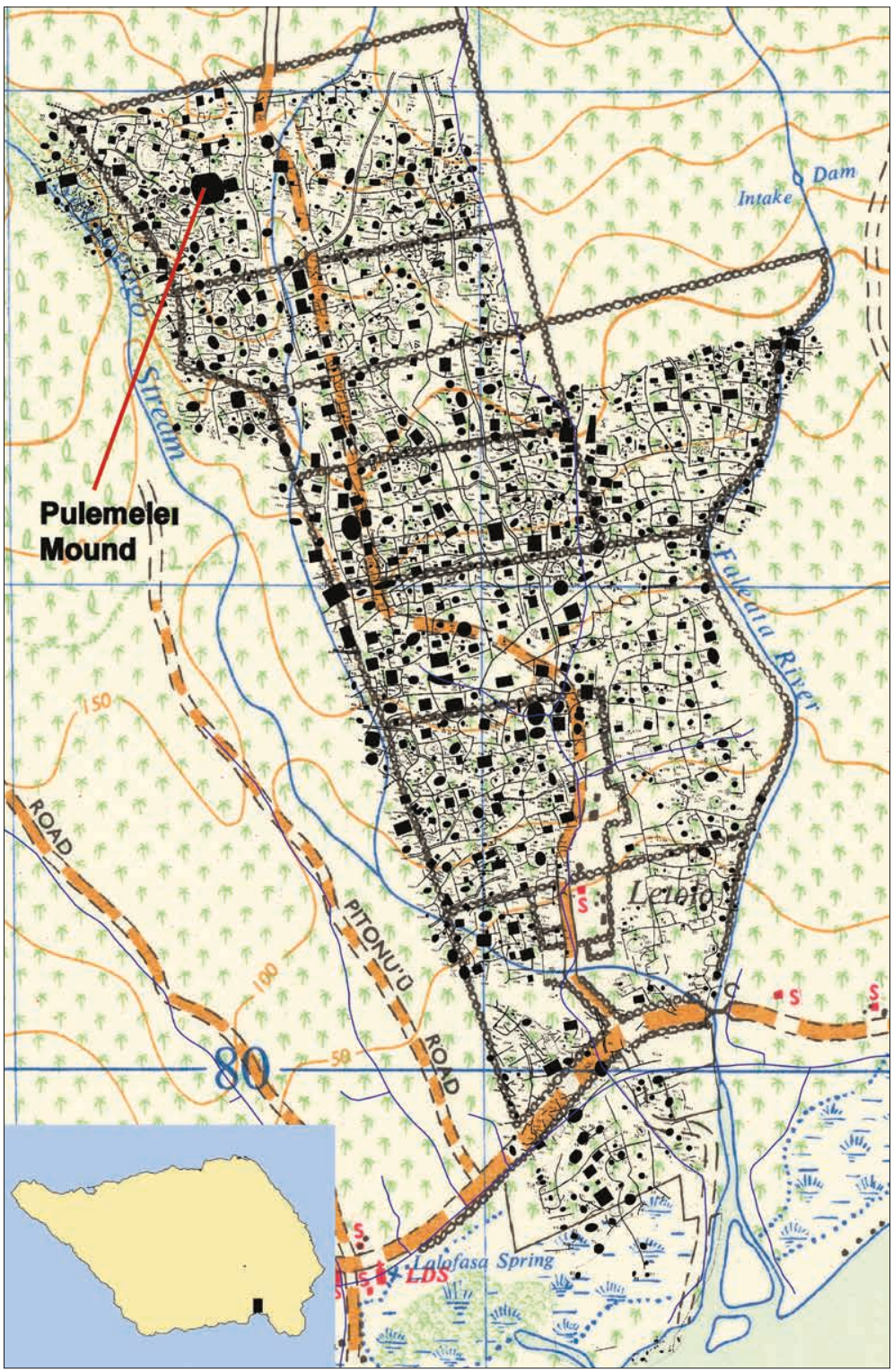

Figure 1. Letolo Plantation Survey, 1978. 
both Savai' $i$ and 'Upolu. A longer-term objective is to assist the Government of Samoa in developing heritage protection polices and legislation that are lacking at present (see Sciusco and Martinsson-Wallin 2015). The research is part of a wider long-term project to locate known archaeological sites, survey and document previously undocumented sites, and map them using GIS with attached information about the sites, including archaeological analysis, historical sources and oral traditions or other information.

\section{Survey Area}

The survey focused on Palauli East District (itūmālō) which comprises the territories of three contiguous villages, Vailoa, Vaito'omuli and $\mathrm{Fa}^{\text {' }}$ aala, located on the coastline (Fig. 3). One village, Sātufia, belonging to the westward district of Sātupa'itea, bisects Palauli East and Palauli Le Falefā, close to the boundary of Letolo (Fig. 2). ${ }^{2}$ Today the three villages of Palauli East are centred on the coast along the road. Behind the village, gently sloping plantation land mixed with forest rises to steeper areas further inland. Several old intrusive lava flows lie mainly above and to the east of Fa'aala. There are three rivers (Vailoa, Faleata and Seugagogo) with intermittent flows into Palauli Bay, depending on rainfall (Fig. 2). Some of the households of these villages have moved inland along the plantation roads onto land previously only used for agriculture. Six years ago the population of the district was recorded at 2,478 (Samoa Bureau of Statistics, Population and Housing Census, 2011). The archaeological surveys of selected sites in the district were done with the cooperation and permission of the matai 'chiefs' of the villages who took a growing interest in the work. Many of them were aware of stone structures inland but tended to think of them as belonging to the time of their grandfathers rather than the more distant past, and related the remains of large walls in the interior to well-known legends of a Tongan occupation of Sāmoa in the past.

\section{LiDAR-Derived Imagery}

At the time of Jackmond's Letolo survey in 1978, mapping was made easier by the fact that cattle on the plantation kept the vegetation down, avoiding the need to undertake extensive clearing. The field survey reported here was guided by LiDAR imagery and aerial photographs. The LiDAR data used was part of the Airborne LiDAR Bathymetric and Topographic Survey of Samoa conducted in the period 6 July to 9 August 2015 for the Ministry of Natural Resources and Environment (MNRE) (Table 1). The LiDAR data were collected by Fugro LADS Corporation Pty Ltd. using the Fugro LADS Mk 3 and RIEGL VQ-820-G LiDAR systems. 
Table 1. Specifications of the LiDAR survey.

\begin{tabular}{|c|c|}
\hline Aircraft Used and Call Sign & Beechcraft King Air A90 - N96Y (Dynamic Aviation) \\
\hline Transit Speed / Height & 175 knots $I \mathrm{Up}$ to $26,000 \mathrm{ft}$ \\
\hline Aircraft Endurance & Up to four hours \\
\hline Survey Operations & $\begin{array}{l}\text { Primarily conducted at } 1,800 \mathrm{ft} @ 145 \text { knots } \\
\text { Small area conducted at } 1,400 \mathrm{ft} @ 145 \text { knots }\end{array}$ \\
\hline \multicolumn{2}{|l|}{$\begin{array}{l}\text { Fugro LADS Mk } 3 \text { LiDAR } \\
\text { Specifications: }\end{array}$} \\
\hline Laser Rate & $1,500 \mathrm{~Hz}$ \\
\hline Laser Spot Spacing & $\begin{array}{l}\text { Primarily conducted at } 5 \times 5 \text { metres }(\mathrm{P} 5) \\
\text { Small area conducted at } 4 \times 4 \text { metres }(\mathrm{P} 4)\end{array}$ \\
\hline Swath Width & 360 metres (P5), 273 metres (P4) \\
\hline Line Spacing & 330 metres (P5), 253 metres (P4) \\
\hline Digital Camera & Redlake MegaPlus II ES 2020 \\
\hline Image Resolution & $>4$ pixels $/ \mathrm{m}$ at an altitude of $1,600 \mathrm{ft}$ \\
\hline Capture Rate & 1 second/frame $(1 \mathrm{~Hz})$ \\
\hline \multicolumn{2}{|l|}{$\begin{array}{l}\text { RIEGL VQ-820-G LiDAR } \\
\text { Specifications: }\end{array}$} \\
\hline Laser Rate & $284 \mathrm{KHz}$ \\
\hline MTA Zone & 2 \\
\hline Laser Power & Full power \\
\hline Field of View (FOV) & $42^{\circ} \mathrm{FOV}$ - gives $32.1 \%(170 \mathrm{~m})$ sidelap for LiDAR \\
\hline Laser Spot Spacing & Nominally 11 points per square metre \\
\hline Scan Speed & 157 lines/second \\
\hline Swathe Width & Nominally 530 metres at $1,800 \mathrm{ft}$. \\
\hline
\end{tabular}

The Centre for Samoan Studies acquired the images of the survey area (with permission from the Government of Samoa) as classified LAS files. The LAS files were first processed into digital elevation models (DEMs) which retained the class 2 (ground) points using the "las2dem" conversion tool in the LAS tools for QGIS (GIS software). Next, the DEMs were rendered into sky-view factor tiffs using the Relief Visualization Toolbox (e.g., Fig. 6b). 


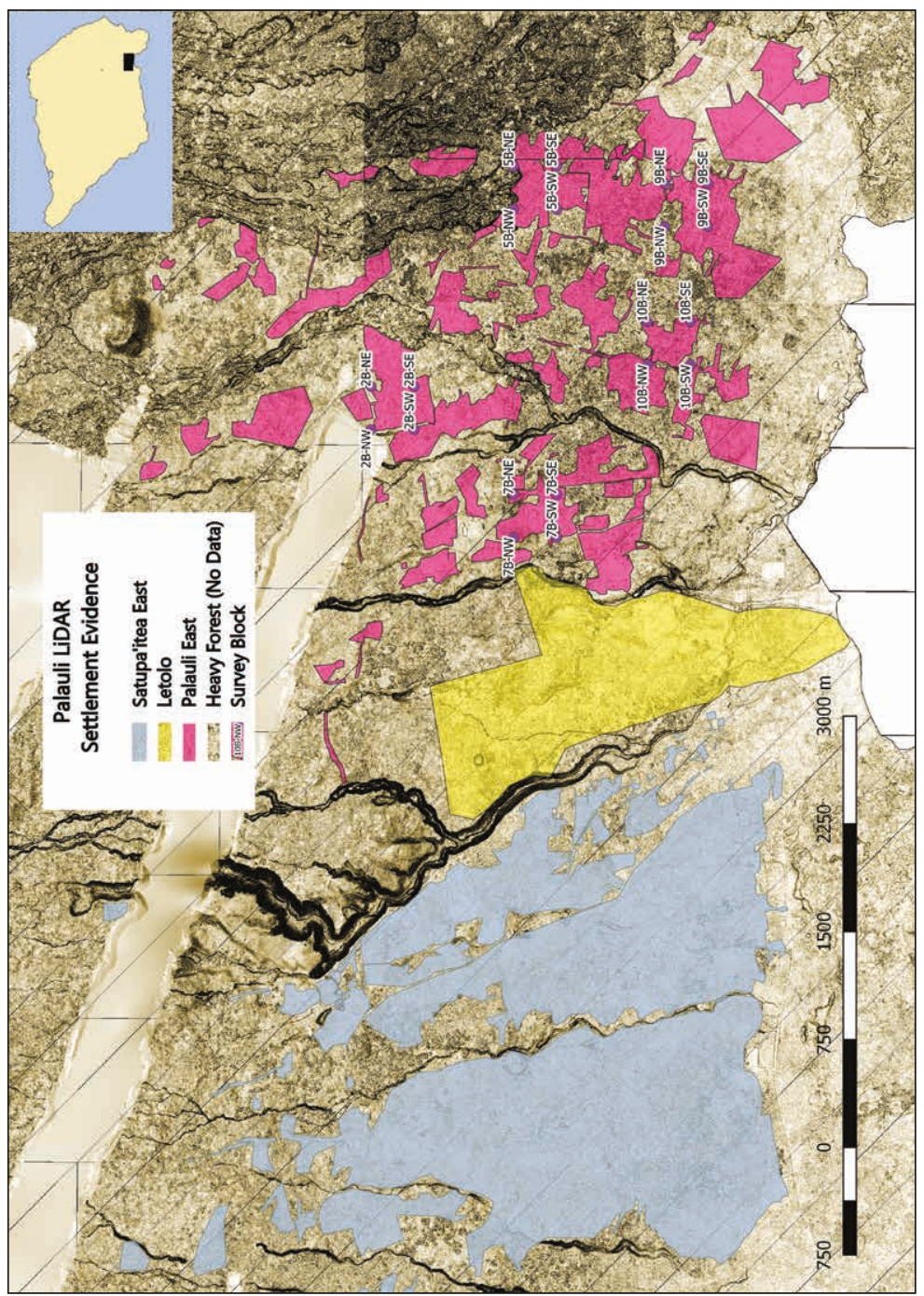

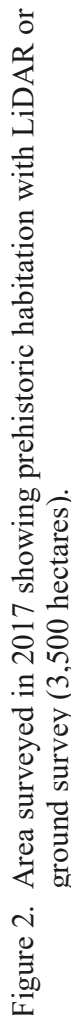


These images of the area comprising the traditional districts Palauli East and Sātupa 'itea East and part of Palauli West (Fig. 2) indicated the existence of an extensive indigenous population zone stretching from the coast to three or more kilometres inland throughout most of the district. Although deep forest cover obscures the LiDAR readings in some areas, those portions of the forest that have been cleared for agricultural purposes show a dense and extensive habitation zone consisting of house platforms, walls, earthen ovens and numerous walled and elevated walkways stretching at times both parallel to the coast and inland for several kilometres. LiDAR-derived images show only a small portion, approximately one-third or less, of the walls, platforms, earth ovens and walkways that have been found by ground survey.

\section{Survey Methods}

The team, comprising five lecturers and 14 students, canvassed five large swathes of bush measuring $300 \times 300 \mathrm{~m}$ inland of each village using Samsung S6 smartphones to record data, take GPS waypoints, photograph features and track their progress. The survey was originally planned as a rough exploratory survey, using a modified checkerboard pattern of non-adjacent blocks. Before blocks were selected for the final intensive ground survey a preliminary reconnaissance was conducted of the possible survey areas using LiDAR, aerial photos and a quick on-the-ground GPS point survey to gauge the feasibility of a ground survey. The selected blocks were then surveyed (see below) to get an idea of the platform density and layout in the Palauli area to compare with what was previously found at the ancient villages of Letolo (1978) and Sāpapali'i (1976), and the modern village of Fa' aala (1979) in Savai'i and the Mt Olo survey in 'Upolu (1976). Given the limited time for the survey and the experience level of the survey team, the original grid pattern was slightly modified, and surveying priority was given to areas of low vegetation which ensured the best possible positive outcome. Five $300 \times 300 \mathrm{~m}$ blocks ( 10 seconds of longitude by 10 seconds of latitude) were eventually selected for the survey (Fig. 3). An intensive ground survey was conducted of the selected blocks.

Teams of three students and one instructor performed a preliminary survey of the selected survey blocks by walking transects and recording the measurements and locations of all archaeological features encountered using standalone Samsung S6 smartphones (not connected to the internet) equipped with the following apps:

(i) Docs To Go (spreadsheet) to record all measurements,

(ii) GPS Status (compass) to measure headings and orientations for recorded features and photographs, 
(iii) SavePoint to record GPS waypoints for all features (within an accuracy of $3 \mathrm{~m})$,

(iv) Camera to photograph all features and record GPS waypoints of the photographs,

(v) QField to view exact locations in the field using selected aerial photographs and LiDAR-derived images of the survey area.

All information was then transferred into QGIS to develop maps and an integrated working database of the survey areas. ${ }^{3}$

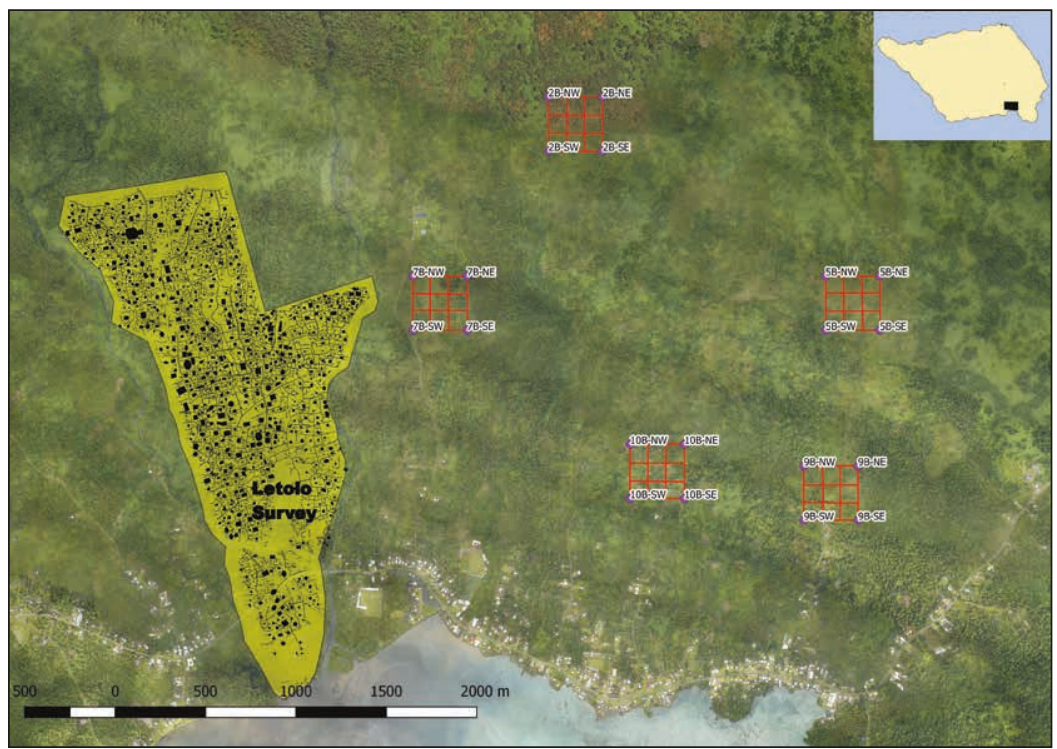

Figure 3. Survey areas in 2017 showing $300 \times 300 \mathrm{~m}$ survey blocks and location of modern villages. The 1978 Letolo Survey is highlighted in yellow for reference.

The first fieldwork session in April 2017, closest to the modern villages, recorded 233 archaeological features after four days in the inland areas of the two villages. Using Hillshade LiDAR images as a comparison (Fig. 4a), the field team was able to locate and record approximately three to five times as many sites (platforms, walls, $u m u$, walkways) in the field survey as were apparent on the Hillshade LiDAR-derived images. Later in June with a now more experienced team and better sky-view LiDAR-derived images (Fig. 4b) the teams returned to the Palauli area to continue their survey. 


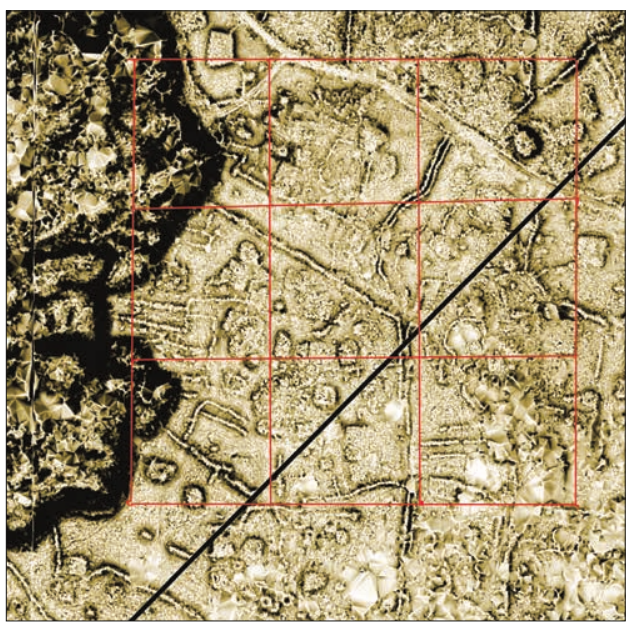

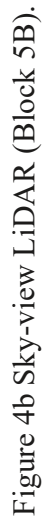
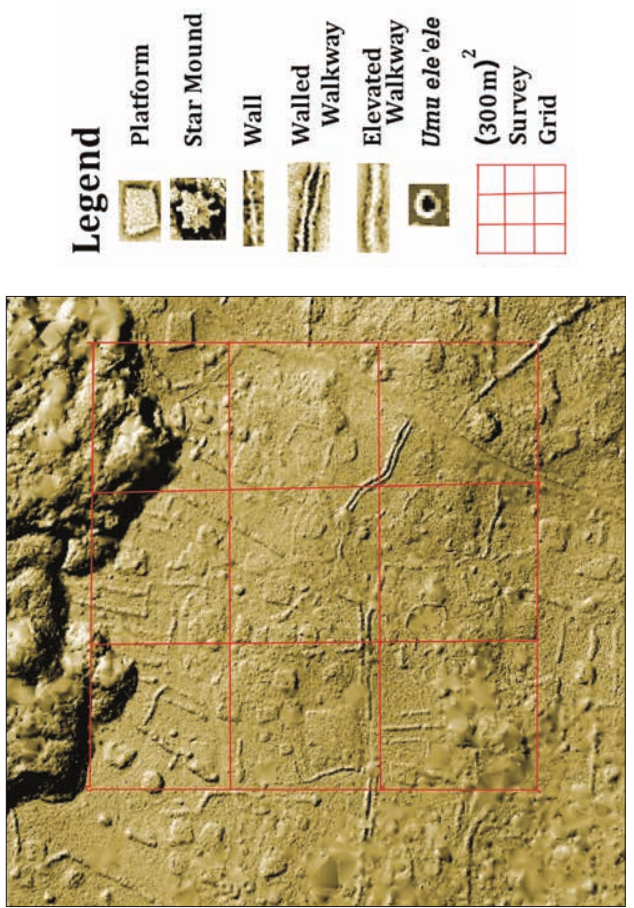

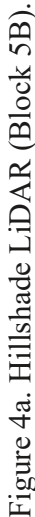


Table 2. Block 10B data.

\begin{tabular}{|lc|}
\hline Apr 4-6 Stats & $\begin{array}{c}\text { Vaito'omuli } \\
\text { (Block 10B) }\end{array}$ \\
\hline Platforms & 56 \\
Walls & 36 \\
Walkways & 5 \\
Umu ele'ele & 2 \\
Stone Piles & 0 \\
Star Mounds & 2 \\
Other & 0 \\
All Sites & 101 \\
\hline
\end{tabular}

\begin{tabular}{|lcrr|}
\hline Platforms: & Length & Width & Area \\
\hline Avg. & 13 & 9 & 134 \\
Max. & 30 & 22 & 660 \\
Min. & 3 & 2 & 6 \\
Median & 12 & 9 & 102 \\
STDEV & 6 & 4 & 117 \\
\hline
\end{tabular}

\begin{tabular}{|c|c|c|c|c|}
\hline \multicolumn{5}{|l|}{ Legend } \\
\hline Platform & $D$ & Walled Walkway & & $(300 \mathrm{~m})^{2}$ \\
\hline Star Mound & $\Delta$ & Elevated Walkway & \begin{tabular}{|l|l|l|} 
&
\end{tabular} & $\begin{array}{l}\text { Survey } \\
\text { Grid }\end{array}$ \\
\hline & * & Umu ele'ele & & \\
\hline
\end{tabular}

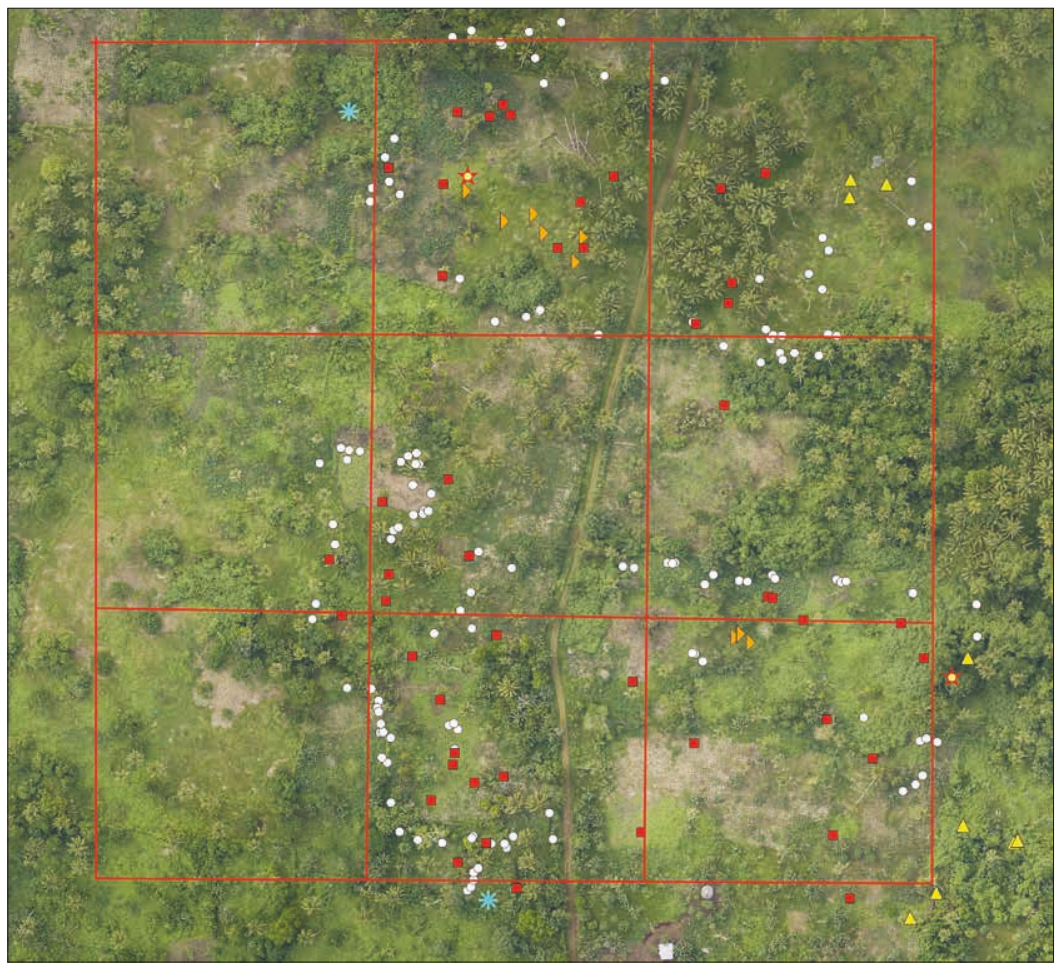

Figure 5. Archaeological features recorded during the April 2017 survey: QGIS Map - Block 10B. 
Table 3. Block 9B data.

\begin{tabular}{|lc|}
\hline Apr 7-8 Stats & $\begin{array}{l}\text { Fa'aala } \\
\text { (Block 9B) }\end{array}$ \\
\hline Platforms & 50 \\
Walls & 46 \\
Walkways & 25 \\
Umu ele'ele & 7 \\
Stone Piles & 0 \\
Star Mounds & 0 \\
Other & 4 \\
All Sites & 132 \\
\hline
\end{tabular}

\begin{tabular}{|c|c|c|c|c|}
\hline Platforms: & & Length & Width & Area \\
\hline Avg. & & 13 & 9 & 143 \\
\hline Max. & & 33 & 25 & 825 \\
\hline Min. & & 3 & 2 & 6 \\
\hline Median & & 12 & 9 & 99 \\
\hline STDEV & & 6 & 5 & 154 \\
\hline Legend & & & & \\
\hline Platform & $D$ & \multicolumn{2}{|c|}{ Walled Walkway } & $(300 \mathrm{~m})^{2}$ \\
\hline Star Mound & $\Delta$ & \multicolumn{2}{|c|}{ Elevated Walkway } & Grid \\
\hline Wall & * & \multicolumn{2}{|c|}{ Umu ele'ele } & \\
\hline
\end{tabular}

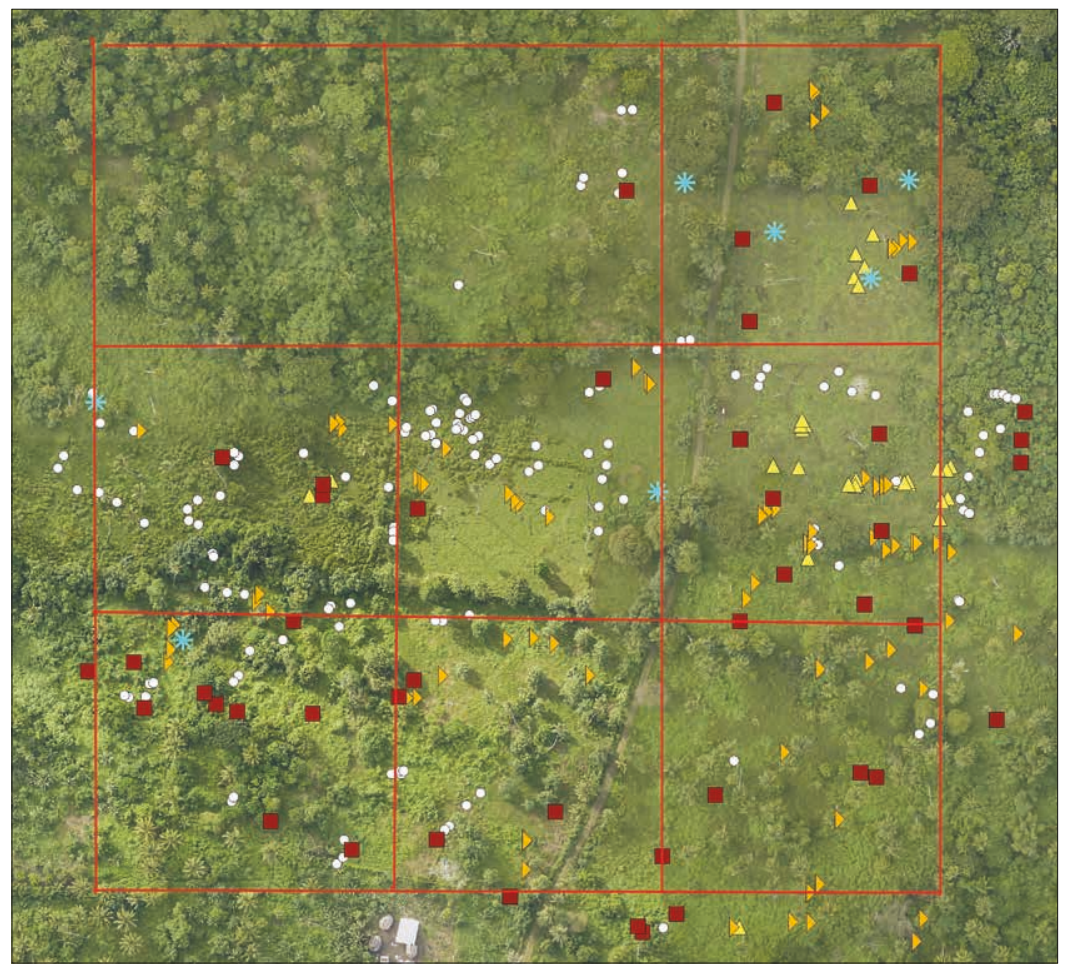

Figure 6. Archaeological features recorded during the April 2017 survey: QGIS Map - Block 9B. 
Table 4. Block 7B data.

\begin{tabular}{|lc|}
\hline Jun 19-20 Stats & $\begin{array}{l}\text { Vailoa } \\
\text { (Block 7B) }\end{array}$ \\
\hline Platforms & 33 \\
Walls & 20 \\
Walkways & 15 \\
Umu ele'ele & 15 \\
Stone Piles & 25 \\
Star Mounds & 1 \\
Other & 6 \\
All Sites & 115 \\
\hline
\end{tabular}

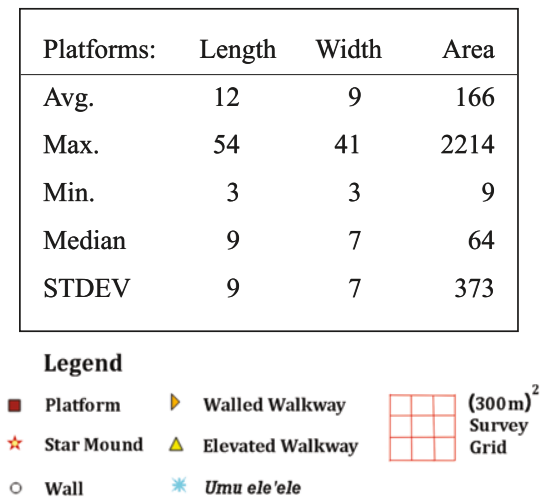

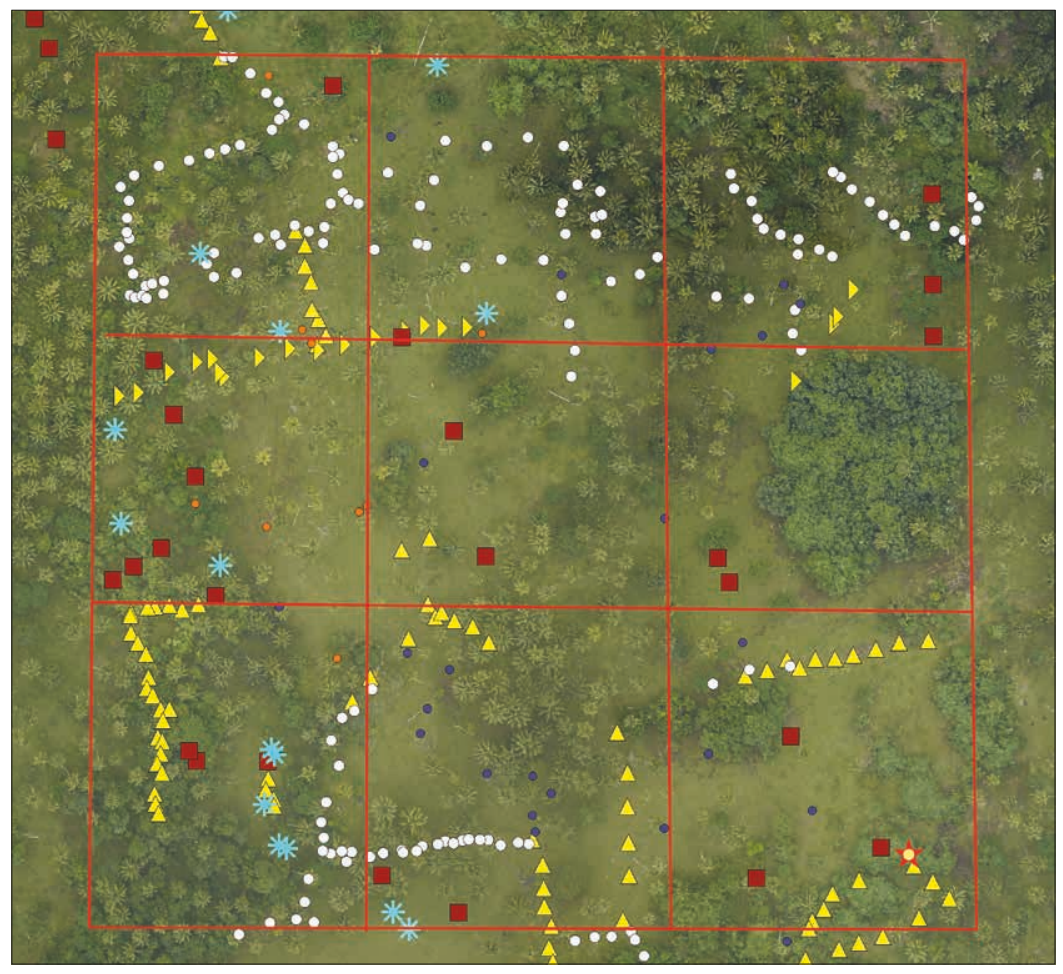

Figure 7. Archaeological features recorded during the June 2017 survey: QGIS Map - Block 7B. 
Table 5. Block 5B data.

\begin{tabular}{|lc|}
\hline Jun 22-26 Stats & $\begin{array}{l}\text { Fa'aala } \\
\text { (Block 5B) }\end{array}$ \\
\hline Platforms & 40 \\
Walls & 27 \\
Walkways & 27 \\
Umu ele'ele & 5 \\
Stone Piles & 5 \\
Star Mounds & 0 \\
Other & 0 \\
All Sites & 104 \\
\hline
\end{tabular}

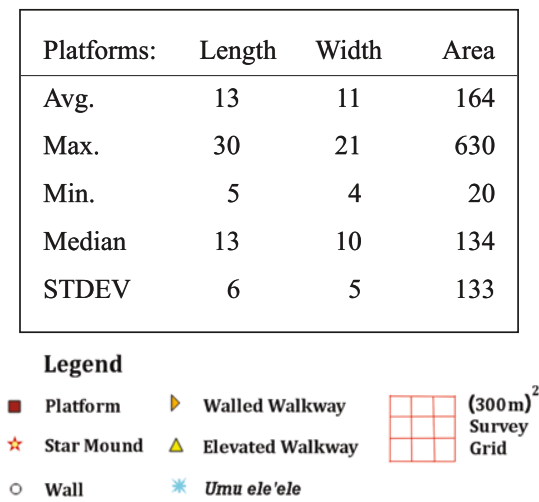

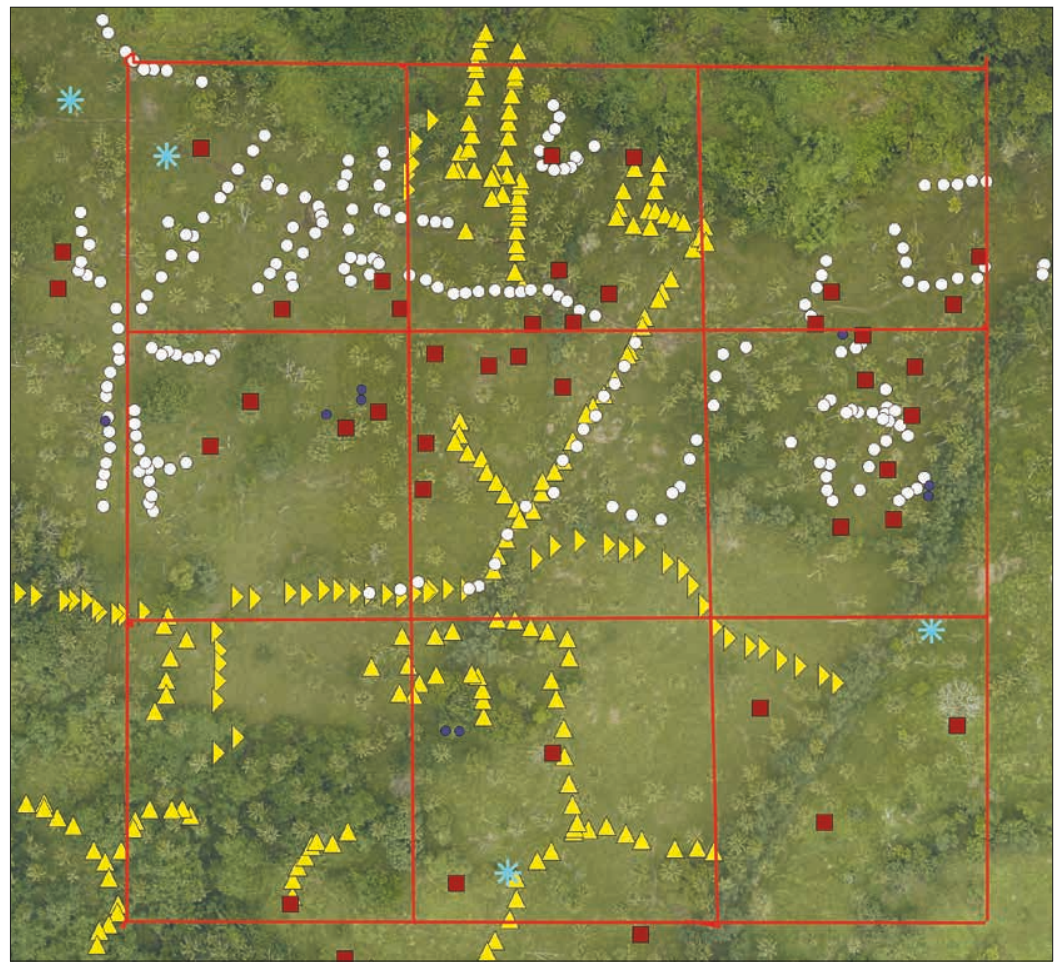

Figure 8. Archaeological features recorded during the June 2017 survey: QGIS Map - Block 5B. 
Table 6. Block 2B data.

\begin{tabular}{|lc|}
\hline Jun 27-29 Stats & $\begin{array}{l}\text { Vaito'omuli } \\
\text { (Block 2B) }\end{array}$ \\
\hline Platforms & 31 \\
Walls & 10 \\
Walkways & 13 \\
Umu ele'ele & 2 \\
Stone Piles & 9 \\
Star Mounds & 0 \\
Other & 0 \\
All Sites & 65 \\
\hline
\end{tabular}

\begin{tabular}{|c|c|c|c|c|}
\hline Platforms: & & Length & Width & Area \\
\hline Avg. & & 12 & 8 & 121 \\
\hline Max. & & 25 & 20 & 500 \\
\hline Min. & & 4 & 3 & 12 \\
\hline Median & & 12 & 8 & 82 \\
\hline STDEV & & 5 & 4 & 111 \\
\hline Legend & & & & \\
\hline Platform & $D$ & \multicolumn{2}{|c|}{ Walled Walkway } & $\begin{array}{l}(300 \mathrm{~m})^{2} \\
\text { Survey }\end{array}$ \\
\hline Star Mound & $\Delta$ & \multicolumn{2}{|c|}{ Elevated Walkway } & \\
\hline Wall & * & \multicolumn{2}{|c|}{ Umu ele'ele } & \\
\hline
\end{tabular}

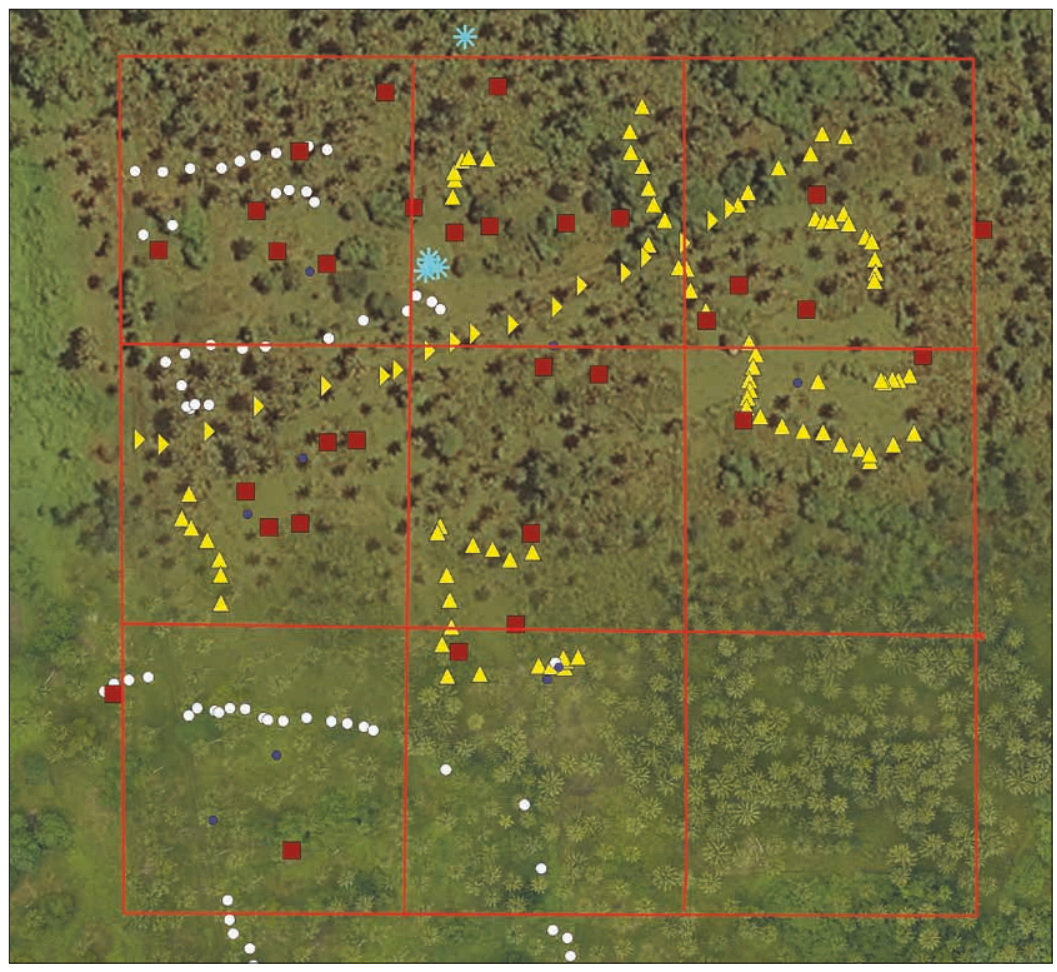

Figure 9. Archaeological features recorded during the June 2017 survey: QGIS Map - Block 2B. 
Survey Findings

During the eight days of fieldwork the team recorded an additional 284 archaeological features in three separate blocks ranging from two to three kilometres inland from the coast where conditions were rougher and the fieldwork slower (see Fig. 3). The general features discovered during the ground survey match those previously described (Buist 1969; Green and Davidson 1964; Jennings 1976; Jennings and Holmer 1980; Jennings et al. 1982; Scott 1969). Some of the feature names are modified here in an effort to add clarity to their descriptions ${ }^{4}$ (see Tables 2-6, Figs. 5-9 for more detailed information).

\section{$* * *$}

The LiDAR images of Palauli East, backed up by our intensive ground survey, show that the settled area documented in 1978 extends far beyond Letolo and proves the existence of extensive indigenous population zones in Palauli stretching from the coast to three or more kilometres inland. These findings, as well as preliminary investigation using other LiDAR-derived images for Savai' $i$ and 'Upolu now being analysed, confirm the evidence from the earlier 'Upolu and Savai'i surveys, as well as recent small-island surveys previously cited, that it was likely that extensive inland settlements existed throughout the archipelago in centuries prior to the 19th century.

More detailed archaeological investigations may be able to show whether documented sites represent different phases of occupation. Such investigations will require years of further research and may eventually provide answers to questions about the pre-contact population of Sāmoa. For example, using the present survey, and assuming contemporaneous inhabitation, a conservative average of $60^{5}$ house platforms can be estimated per 10 hectares surveyed. Taking only one-tenth of those platforms (6) as occupied at any one time, with only five occupants per house platform $(6 \times 5=30)$ and multiplying by only 2,000 hectares $(4 \times 5 \mathrm{~km})$ (of the over 6,300 hectares available in the Palauli area $(7 \times 9 \mathrm{~km})$ gives us an estimated population of at least 6,000 (6 platforms per 10 hectares; $2,000 / 10=200$ of the 10 -hectare blocks; $200 \times 30=6000$ ), that is about twice the population of 2,478 recorded in the 2011 Census. This suggests the possibility that Sāmoa had a population several orders of magnitude greater than the previous estimates we cite above.

The continuous mass of settlement expansion in all directions in Palauli does not appear to be contemporaneous given the above population estimate for only $10 \%$ habitation and historical evidence of modern platform occupation (Jennings et al. 1982). However, it will not be easy to provide a chronology for these locations, as the deep horizontal strata used in archaeology for the relative temporal placement of objects may be lacking. With this in mind, objects right next to each other spatially can be hundreds or even thousands of years apart temporally, due to the Sāmoan practice of recycling previously 
occupied house platforms, terraces and walls, either in part or as a whole. When building "new" structures any available materials, old platforms, walls or piles of stone may be used, modifying again the complex temporal and spatial interactions of these structures.

With all of this to consider, settlement patterns in Sāmoa are extremely complex. Through our work in Palauli we are just starting to get a glimpse of the ramifications of our findings. They raise many questions beyond settlement, land use and population. What was the purpose of the long walled and elevated walkways? Were the star mounds built for the purpose of catching pigeons or did they have other significance? Were the many large ground ovens ( иmu ele 'ele) built to extract sugar from the roots of $t \bar{l}$ plants (Cordyline sp.) or for other purposes? Was a large earth mound of approximately the same vertical dimensions as the Pulemelei the base of an interrupted work in progress? To understand the meaning and temporal aspects of what we have found in Palauli (and other inland areas of Sāmoa currently being investigated) will undoubtedly take many more years of work.

\section{ACKNOWLEDGEMENTS}

The research was inspired and encouraged by Prof. Helene Martinsson-Wallin (Uppsala University, Sweden) who, since 2005, has worked closely as an Adjunct Professor with the Centre for Samoan Studies at the National University of Samoa to provide training and encouragement for teaching and research on archaeology and cultural heritage. This was initially funded by a Linnaeus-Palme academic exchange grant from the Swedish International Development Cooperation Agency.

\section{NOTES}

1 LiDAR stands for light detection and ranging, a remote-sensing method (that uses the same principle as radio detection and ranging - RADAR - except that it uses a laser instead of radio waves) using light in the form of a pulsed laser to measure ranges (variable distances) to the earth's surface.

2 Palauli District, Savai' $i$, has three traditional subdistricts: Palauli East, Palauli Le Falefāa and Palauli West.

3 No excavations were performed during this field survey. Because of dense vegetation and time constraints only about $65-75 \%$ of each survey block $(300 \times 300 \mathrm{~m})$ was covered during the field survey; unsurveyed areas are evident in the figures by the lack of mapped sites (features).

4 "Umu-tıे", meaning an earthen oven used to cook the $t \bar{\imath}$ plant, has been referred to in more general terms as an uти ele 'ele, literally "earthen oven"; roadways are referred to by the more generic term of "walkways", and rather than attempt to set some arbitrary size limit between platforms and mounds, all are referred to as simply platforms.

5 For example: Block 10B: 56 platforms found in area surveyed $/ 0.7$ part of block surveyed $=80$ platforms; Block 9B: 50 platforms found in area surveyed $/ 0.7$ part of block surveyed $=71$ platforms; Block $7 \mathrm{~B}: 33 / 0.7=47 ; 5 \mathrm{~B}: 40 / 0.7=57$; $2 \mathrm{~B}: 31 / 0.7=44 ;(80+71+47+57+44) / 5=59.8$ for a 9 -hectare block. Therefore we estimate approximately 60 platforms per 10 hectares. 


\section{REFERENCES}

Buist, A.G., 1969. Report 3: Field archaeology on Savaii. In R.C. Green and J.M. Davidson (eds), Archaeology in Western Samoa, Vol. 1. Auckland: Bulletin of the Auckland Institute and Museum, pp. 34-60.

Davidson, J.M., 1969. Settlement patterns in Samoa before 1840. Journal of the Polynesian Society 78 (1): 44-82.

Green, R.C. and J.M. Davidson, 1964. Preliminary Report on Archaeological FieldWork in Western Samoa. Department of Anthropology, University of Auckland, Auckland (mimeographed).

Green, R.C., 2007. Protohistoric Samoan population. In P.V. Kirch and J-L. Rallu (eds), The Growth and Collapse of Pacific Island Societies: Archaeological and Demographic Perspectives. Honolulu: University of Hawai'i Press, pp. 203-31.

Golson, J., 1969. Report 1: Preliminary research: Archaeology in Western Samoa. In R.C. Green and J.M. Davidson (eds), Archaeology in Western Samoa, Vol. 1. Auckland: Bulletin of the Auckland Institute and Museum, pp. 14-20.

Jennings, J.D., R.N. Holmer and G. Jackmond, 1982. Samoan village patterns: Four examples. Journal of the Polynesian Society 91: 81-102.

Jennings, J.D. and R.N. Holmer, 1980. Archaeological Excavations in Western Samoa. Pacific Archaeological Records No. 32. Honolulu: Department of Anthropology, Bernice P. Bishop Museum.

Jennings, J.D., R.N. Holmer, J. Janetski and H.L. Smith, 1976. Excavations on Upolu Western Samoa. Pacific Archaeological Records No. 25. Honoulu: Department of Anthropology, Bernice P. Bishop Museum.

McArthur, N., 1967. Island Populations of the Pacific. Canberra: Australian National University Press.

Martinsson-Wallin, H., 2016. Samoan Archaeology and Cultural Heritage: Monuments and People, Memory and History. Oxford: Archaeopress Publishing Ltd.

Pirie, P., 1963. Geography of Population in Western Samoa. PhD, Australian National University, Canberra.

Pratt, G., 1893. A Grammar and Dictionary of the Samoan Language, with English and Samoan Vocabulary. London Missionary Society, Third and Revised Edition, reprinted by Southern Reprints, Papakura, New Zealand.

Quintus, S.J., 2015. Dynamics of Agricultural Development in Prehistoric Samoa: The Case of Ofu Island. Unpublished PhD thesis, University of Auckland, Auckland.

Quintus, S., J.T. Clark, S.S. Day and D.P. Schwert, 2015. Investigating regional patterning in archaeological remains by pairing extensive survey with a lidar dataset: The case of the Manu'a Group, American Samoa. Journal of Archaeological Science: Reports 2: 677-87.

Quintus, S., S.S. Day and N.J. Smith, 2017. The efficacy and analytical importance of manual feature extraction using lidar datasets. Advances in Archaeological Practice 5(4): 351-64.

Sand, C., J. Bolé, and D. Baret, 2012. Archaeology of Manono Island (Samoa): First Field Program Report. Nouméa: apport de mission de l'Institut d'archéologie de la Nouvelle-Calédonie et du Pacifique. Technical Report.

Sand, C., D. Baret, J. Bolé, and A.J. Ouetcho, 2013. Manono Archaeology Project Field Report 2013.Nouméa: Rapport de mission de l'Institut d'archéologie de la Nouvelle-Calédonie et du Pacifique. Technical Report.

Sciusco, L. and H. Martinsson-Wallin, 2015. Issues in the management of archaeo- 
logical heritage in Samoa. Journal of Samoan Studies 5: 1-16.

Scott, S.D., 1969. Report 4: Reconnaissance and some detailed site plans of major monuments of Savaii. In R.C. Green and J.M. Davidson (eds), Archaeology in Western Samoa, Vol. 1. Auckland: Bulletin of the Auckland Institute and Museum, pp. 61-90.

Watters, R.F., 1958. Settlement in Old Samoa: 1840. New Zealand Geographer 15: 1-18.

Wright, C.S., 1963. Soils and Land Use of Western Samoa. Wellington: Government Printer (Soil Bureau Bulletin 22: 91-94).

\begin{abstract}
This communication presents results from LiDAR-guided field research in 2017 which revealed the existence of continuous indigenous population zones stretching from the coast to three or more kilometres inland across the district of Palauli East, Savai' $i$. The findings amplify archaeological evidence of a small number of inland settlements (recorded in the 1970s and earlier) on the main islands of 'Upolu and Savai' $i$ as well as recent studies of the small islands of the Manu'a group and Manono. They build the case that in centuries prior to the 19th century inland settlement was far more extensive and villages were not, as had been widely assumed, mainly located on the coast. The findings also support contentions that Sāmoa may have had a much larger population in previous centuries than that indicated by missionary estimates of the mid-19th century.
\end{abstract}

Keywords: Sāmoa, settlement pattern archaeology, pre-contact populations, LiDAR imaging, Polynesia

\title{
CITATION AND AUTHOR CONTACT DETAILS
}

Jackmond, ${ }^{1}$ Gregory, Dionne Fonoti ${ }^{2}$ and Matiu Matavai Tautunu, ${ }^{3}$ 2018. Sāmoa's hidden past: LiDAR confirms inland settlement and suggests larger populations in pre-contact Sāmoa. Journal of the Polynesian Society 127 (1): 73-90. DOI: http:// dx.doi.org/10.15286/jps.127.1.73-90

${ }^{1}$ Corresponding author: Research Archaeologist, Centre for Samoan Studies, National University of Samoa, P.O. Box 1622, Apia, Samoa. Email: g.jackmond@nus.edu.ws

2 Archaeology and Cultural Heritage, Centre for Samoan Studies, National University of Samoa, P.O. Box 1622, Apia, Samoa. Email: d.fonoti@nus.edu.ws

${ }^{3}$ Samoan Language and Culture, Centre for Samoan Studies, National University of Samoa, P.O. Box 1622, Apia, Samoa. Email: m.tautunu@nus.edu.ws 